\title{
Attention-direction versus retrieval practice: which fosters the productive recall of German formulaic sequences best?
}

Griet Boone

Griet.Boone@UGent.be

June Eyckmans

June.Eyckmans@UGent.be

Department of Translation, Interpreting and Comunication

Universiteit Gent, Belgium

\begin{abstract}
This article reports on a classroom-based (quasi)-experiment with a pre-test post-test design that explored the effect of two types of activities on the productive recall of German formulaic sequences (FS): 1) attention-directing activities and 2) retrieval practice. Two intact classes of Dutch-speaking university students of German participated in the study. One class was randomly assigned to the attention-directing condition $(n=18)$, the other one to the retrieval condition $(n=11)$. Twenty-two target FS were selected as learning items. Each group processed the FS in a different condition. In the attention-directing condition, students had to 1) re-read a video transcript with the FS in bold typeface and 2) translate the targets into Dutch. In the retrieval condition, students had to 1) complete a transcript in which the FS were deleted and 2) translate the targets into German. Results indicate that the retrieval condition led to better productive phrase learning than the attention-directing condition.
\end{abstract}

Keywords: formulaic sequences; foreign language acquisition; language teaching; attention-directing; retrieval practice

\section{Zusammenfassung}

In diesem Artikel wird ein (Quasi)-Experiment im Fremdsprachenunterricht mit einem Prätest-Posttest-Design vorgestellt, das die Auswirkungen zweier Arten von Aktivitäten auf die produktive Wiedergabe deutscher formelhafter Sequenzen (FS) untersuchte: 1) Aufmerksamkeitsfokussierungsaktivitäten und 2) aktivem Gedächtnisabruf(engl.retrievalpractice).ZweiLerngruppenvonniederländischsprachigen DaF-Studierenden nahmen an der Studie teil. Achtzehn Studierenden wurde 
willkürlich die Lerngruppe mit Aufmerksamkeitsfokussierungsaktivitäten zugewiesen, elf Studierenden die Lerngruppe mit Gedächtnisabrufaktivitäten. Zweiundzwanzig formelhafte Sequenzen wurden als Zielobjekte ausgewählt und jede Lerngruppe behandelte die FS in einer anderen Lernumgebung. In der Lernumgebung der Aufmerksamkeitsfokussierung mussten die Studierenden 1) das Transkript mit fettgedruckten FS lesen und 2) die Zielobjekte ins Niederländische übersetzen. In der Lernumgebung mit den Gedächtnisabrufaktivitäten mussten sie 1) das Transkript, in dem die FS vorher gelöscht wurden, als Lückentext ergänzen und 2) die Zielobjekte ins Deutsche übersetzen. Die Ergebnisse deuten darauf hin, dass aktiver Gedächtnisabruf zu einem produktiveren Lernen formelhafter Sequenzen führt im Vergleich zu den Aufmerksamkeitsfokussierungsaktivitäten.

Stichwörter: formelhafte Sequenzen; Fremdsprachenerwerb; Sprachdidaktik; Aufmerksamkeitsfokussierung; aktiver Gedächtnisabruf

\section{Introduction}

In the last decennia, formulaic sequences (FS) have been a popular object of study, not only in first and second language (L1 and L2) acquisition research, but also in grammatical theory, psycholinguistics and corpus linguistics (Wray, 2009). This has led to a plethora of terms for this phenomenon: multiword units, lexical chunks, formulas, prefabs, lexical phrases are but a few of the terms that have been put forward in the literature.

Mastery of formulaic sequences, in all their various guises (i.e. collocations, idioms, proverbs and so forth) has been shown to be an essential component of successful language learning and use (e.g. Meunier \& Granger, 2008; Sinclair, 1995; Wray, 2002). Apart from the general consensus about the importance of FS in foreign language learning and teaching, it is also widely accepted that they are a stumbling block for L2 learners (e.g. Conklin \& Schmitt, 2008; Laufer \& Waldman, 2011).

Different studies have demonstrated that L2 learners need help when learning FS and that the development of a repertoire of FS needs to be supported by language instruction processes (e.g. Meunier, 2012; Szudarski, 2017). Several pedagogical attempts to promote the teaching of L2 phrases have been put forward since the 1990s. However, there is still a need for more empirical research on the effectiveness of pedagogical techniques with a view to language production. Furthermore, the majority of the studies in this field focus on English as a second or foreign language, on figurative idioms or on academic FS. Studies on teaching formulaic language in other languages such as German, the most widely spoken mother tongue in the 
European Union, or studies in which non-academic FS from natural discourse are integrated in classroom activities, are rare. The current study aims to explore the effect of two pedagogical activities, namely attention-directing or awareness-raising activities and retrieval practice, on the productive recall of German FS in a classroom context. Attention-direction is a well-established approach for teaching FS in the foreign language classroom, but most studies focus on its effect on recognition, not on production. Retrieval practice is a technique that has been shown to foster productive knowledge of L1 and L2 vocabulary, but that has hardly been the focus of research when it comes to FS. The aim of the present study is, therefore, to weigh the efficiency of attention-directing activities and retrieval practice for L2 phrase learning against each other.

\section{Literature review}

\subsection{Formulaic sequences in foreign language acquisition}

One of the most cited definitions of a formulaic sequence is undoubtedly the one by Wray (2002:9): "a sequence, continuous or discontinuous, of words or other elements, which is, or appears to be, prefabricated: that is, stored and retrieved whole from memory at the time of use, rather than being subject to generation or analysis by the language grammar." Wray (2008) makes a clear distinction between a speakerexternal approach to formulaicity (i.e. what is formulaic in the language, for example collocations like raise doubts, idiomatic expressions like once in a blue moon, pragmatic formulas like have a nice day, etc.) and a speaker-internal or psycholinguistic approach (i.e. what is formulaic for an individual learner, namely which sequences are stored holistically and retrieved more easily than others by this learner). Especially in studies with L2 learners, where the focus mainly lies on the appropriate use of collocations, idioms, etc., a speaker-external approach to formulaicity is often adopted (e.g. Laufer \& Waldman, 2011; Nesselhauf, 2003; Paquot \& Granger, 2012). This also applies to this study, in which we define FS as linguistic clusters (Myles \& Cordier, 2017:10): "multimorphemic clusters which are either semantically or syntactically irregular, or whose frequent co-occurrence gives them a privileged status in a given language as a conventional way of expressing something."

In foreign language acquisition, mastery of formulaic sequences has been shown to be pivotal for successful language learning and use (e.g. Ellis \& Simpson-Vlach, 2009; Meunier \& Granger, 2008; Nattinger \& DeCarrico, 1992; Schmitt, 2004; Sinclair, 1995; Wray, 2002). First, research in corpus linguistics has revealed that FS are widespread in spoken and written native discourse (e.g. Erman \& Warren, 
2000; Meunier, 2012; Sinclair, 1995). FS are therefore essential if one aims to reach a native-like level of proficiency, especially with a view to the production of idiomatic language (Cowie, 1992; Pawley \& Syder, 1983). Using FS has been shown to reduce the cognitive load that L2 processing poses on learners, leading to a more fluent and accurate L2 speech (e.g. Ellis, Simpson-Vlach, \& Maynard, 2008; Wood, 2006, 2010, 2012). Finally, there is considerable evidence that L2 learners' language production is considered as more proficient when FS are used, in both L2 speaking and writing (e.g. Boers, Eyckmans, Kappel, Stengers, \& Demecheleer, 2006; Ellis, 2001; Nesselhauf, 2003).

Apart from the studies that demonstrate the importance of FS for foreign language learning, there is general consensus that the acquisition of formulaic language is slow (e.g. Boers, Lindstromberg, \& Eyckmans, 2014; Laufer \& Waldman, 2011) and difficult for language learners (e.g. Bahns \& Eldaw, 1993; Conklin \& Schmitt, 2008), especially at a productive level (Peters, 2016). It has been shown that L2 language use is characterized by an overuse, underuse, and/or misuse of native-like chunks, even at advanced levels (Nesselhauf, 2003; Durrant \& Schmitt, 2010). Many reasons have been put forward to explain the fact that FS are a stumbling block. First, a correct use of FS requires a sensitivity to native speakers' preferred word combinations, and learners usually do not have sufficient exposure to be able to recognize and process these units as recurring lexical units (e.g. Durrant \& Schmitt, 2010; Wray, 2000; Yamashita \& Jiang, 2010). Second, FS are often not noticed, because learners do not tend to focus their attention on the sequence as a whole but rather on individual words (Barfield \& Gyllstad, 2009). Moreover, language learners often assume that FS in other languages are similar to those in their mother tongue and consequently L2 learners produce them through a process of L1 transfer, resulting in erroneous FS in the target language (e.g. Biskup, 1992; Granger, 1998; Nesselhauf, 2003; Paquot \& Granger, 2012).

\subsection{Teaching formulaic sequences}

From the previous, it is clear that L2 learners need support in acquiring FS. Fortunately, several pedagogical attempts to promote the teaching of L2 phrases have been put forward. In the nineties, Willis (1990), Nattinger and DeCarrico (1992) and Lewis (1993) made recommendations on how to introduce FS in the classroom, although only limited empirical research on how to teach FS effectively was available. Twenty years later, Boers and Lindstromberg (2012) presented an extensive review of experimental and intervention studies on pedagogical treatments that are likely to be helpful for L2 learners' acquisition of FS. One of the techniques that has been shown to be effective, is directing learners' attention to formulaic sequences. These attention-directing activities are in line with Lewis' Lexical Approach (1993) 
and are focused at raising learners' awareness of the lexical nature of language. The idea behind it is that learners would start noticing FS outside the classroom, which would then foster autonomous learning of FS. Other scholars have used attentiondirection through text chunking (e.g. Boers et al., 2006; Jones \& Haywood, 2004; Stengers, Boers, Housen, \& Eyckmans, 2010) or typographic enhancement (e.g. Boers, Demecheleer, He, Deconinck, Stengers, \& Eyckmans, 2017; Choi, 2017; Peters, 2012; Sonbul \& Schmitt, 2013; Szudarski \& Carter, 2016) and have revealed beneficial effects. Drawing learners' attention to prevalent sound repetition in FS (alliteration, assonance, rhyme) has also been shown effective for recalling formulaic sequences (Boers \& Lindstromberg, 2005; Boers, Lindstromberg, \& Eyckmans, 2012; Eyckmans, \& Lindstromberg, 2017; Lindstromberg, \& Eyckmans, 2014), as well as using mental imagery to help learners remember the meaning of figurative idioms (Steinel, Hulstijn \& Steinel, 2007; Szczepaniak \& Lew, 2011).

Recent studies have demonstrated that explicit teaching of FS results in learning gains. Dictogloss exercises for example have shown to be promising to promote the learning of academic FS and collocations (e.g. Lindstromberg, Eyckmans, \& Connabeer, 2016; Snoder \& Reynolds, 2019). Pérez Serrano (2018) investigated which type of instruction fosters chunk recognition and compared attention-directing techniques with explicit vocabulary exercises. In both approaches, participants showed learning gains, but the ones obtained through explicit exercises were higher than those obtained through attention-directing techniques. Webb and Kagimoto (2009) compared the effects of receptive and productive vocabulary tasks on learning collocations and showed that both tasks led to significant learning gains. Peters and Pauwels (2015) investigated the effect of different activities on students' recognition, cued output and spontaneous use of academic FS. Students were offered different types of activities: recognition activities, cued output activities or a combination of both. The authors' tentative conclusion is that activities containing cued output might be more beneficial than recognition activities, both at a productive and receptive level. In a study of Laufer and Girsai (2008), in which they examined the effect of contentoriented tasks, text-based vocabulary tasks and translation tasks (L1-L2 and L2-L1) on the acquisition of collocations, translation exercises were found to be most effective.

Overall, many researchers agree that FS are fundamental to language learning and use, and, as a consequence, need to be explicitly addressed in teaching. As there is still a need for more empirical research on the effectiveness of pedagogical techniques, the present study aims to explore the effect of two pedagogical activities, namely attentiondirecting techniques and retrieval practice, on the productive recall of German FS.

Drawing the attention to the form of the L2 is known to be necessary for successful language learning (e.g. Robinson, 1995; Schmidt, 1990). As mentioned before, there 
is a growing number of studies that employ awareness-raising activities with a view to FS learning. However, the majority of the studies focus on receptive recall, and only a few on productive recall. One study that focused on (oral) production of FS and that was carried out during a general proficiency course of 22 teaching hours, showed that students who were made aware of L2 word combinations and engaged in frequent chunking activities in the classroom, used significantly more FS in their conversations in comparison with a control group, engaged in more traditional (grammarvocabulary) classroom activities (Boers et al., 2006). Another study that focused on the productive recall of FS is a study by Peters (2012), in which two attention-drawing techniques were compared: 1) directing the attention of the learners to FS in a text (instructional method) and 2) typographic salience (bold typeface and underlined). It was demonstrated that typographic salience of the targets had a positive effect on L2 learners' recall of the FS, whereas directing learners' attention did not.

Retrieval practice, also known as the "testing effect", involves the active recall of information from memory. This means that after a learning phase, learners engage in a series of activities (e.g. take a quiz or a test), where they are required to retrieve the learned knowledge, which is supposed to demand a lot of effort from the learner (Karpicke, 2017). As Karpicke (2017:5) writes: "Effortful retrieval of knowledge leaves that knowledge strengthened, increasing the likelihood that it can be accessed and used again in the future." Retrieval practice has proven to be a powerful tool for long-term retention (e.g. Karpicke \& Roediger, 2008; Roediger \& Butler, 2011) and enhances learning more than does repeated rehearsal, for example (Roediger $\&$ Karpicke, 2006). Benefits have been demonstrated in different areas of study and among researchers there is a strong consensus that retrieval practice is beneficial to learning foreign vocabulary (e.g. Barcroft, 2007; Goossens, Camp, Verkoeijen, \& Tabbers, 2014; Kang, Lindsey, Mozer, \& Pashler, 2014; Karpicke \& Smith, 2012; van den Broek, Takashima, Segers, \& Verhoeven, 2018). However, these studies concern individual word learning with word lists or word pairs, and not the uptake of L2 FS. To our knowledge, only the study of Peters and Pauwels (2015) mentions retrieval explicitly as a learning activity to acquire FS. They state that in their study, the cued output activities (gap filling and rephrasing activities) can be considered as "retrieval" activities.

\section{The study}

\subsection{Research questions and hypotheses}

As we have seen in the literature review, there is some evidence that language students learn FS effectively through attention-drawing techniques, although benefits 
were attested mainly with reference to receptive knowledge. The present study will focus on productive knowledge. The effect of attention-directing activities (= typographic salience and translation into L1) on productive recall will be explored. The combination of both activities is intended to raise the chance that the FS are noticed and retained. The attention-directing condition will be compared to a retrieval condition, because this is a method that calls for further investigation when it comes to the learning of FS. The aim of the study was twofold: to see which technique is more powerful to learn lexical phrases at a productive level and to investigate which technique is more beneficial for long-term retention.

The following research questions were addressed:

(1) Which of these conditions (attention-direction or retrieval practice) leads to the largest uptake of FS?

(2) Is the difference in uptake maintained over time?

Because the findings regarding the benefits for single word acquisition through retrieval practice are quite robust, we hypothesize that retrieval practice will lead to higher learning gains than the attention-directing activities. Along those same lines, we predict that learners of the retrieval condition group will be able to produce more target FS in a delayed post-test, two months after the intervention.

\subsection{Methodology}

\subsubsection{Design}

A classroom-based controlled (quasi)-experiment was set up and two intact classes were randomly assigned to either an attention-directing condition or a retrieval condition. A combination of a within-subject and a between-subject design with a pre-test, immediate post-test and two delayed post-tests was adopted. To guarantee that results would be directly comparable, the target items tested in the pre-, post-, and delayed post-tests were identical. Students were not informed of the fact that they would be tested on their productive knowledge of the German FS.

\subsubsection{Participants}

Participants in this study were two intact classes of Dutch-speaking students in their second bachelor year of an Applied Linguistics program at a large Belgian 
university, who were majoring in German and an additional foreign language of their choice. Their ages ranged between 19 and 22. The experiment was conducted during a German course that aims to improve students' oral production in German. This course consisted of a weekly two-hour class over a period of 12 weeks. All students received 190 contact hours of formal instruction in German before the start of the study and their proficiency level for German was assessed at the B1 level for production and at the B2 level for comprehension according to the Common European Framework of Languages (Council of Europe, 2001). The students were administered the Productive Vocabulary Test for German, developed by the Institute for Test Research and Test Development, in cooperation with the Herder-Institute Leipzig and the University of Leipzig. The vocabulary levels of German (1000, 2000, 3000,4000 and 5000) are based on the frequency lists developed from the Herder/ BYU-corpus (Jones, Tschirner, Goldhahn, Buchwald, \& Ittner, 2006). To pass the test, participants need to score 14 out of 18 items per level. All students, except for one, passed the test for the 1000 level, and almost two-thirds passed the test for the 2000 and 3000 level. Nobody reached the 4000 or 5000 level, which means that the participants constitute a rather homogenous group in terms of their level of productive vocabulary knowledge.

Thirty-four students participated in the session in which the pre-test (i.e. a gapfill-exercise, including the 22 target items), the pedagogical intervention and the immediate post-test (i.e. a sight translation, including the same 22 target items) were carried out. One week later, 32 students participated in the delayed post-test, which consisted of the same gap-fill-exercise as in the pre-test. One student was excluded from the experiment, because she made a wordlist during class and used it to complete the immediate and delayed post-test. After two months, the same post-test was administered to both groups, without prior notice. Only 29 students (5 male, 24 female) attended class this time, resulting in 18 participants for the attention-directing condition and 11 for the retrieval condition.

\subsubsection{Target items}

For this study, 22 target items were selected from the transcript of a German video-recording, a text of 335 words. This short informative German video-recording was chosen for three reasons: (1) Authenticity: as it was taken from ARD, the German public broadcaster, it was not specifically designed for teaching purposes. In other words, the FS used in the video-recording were part of authentic German spoken discourse and meet Nesselhauf's criterion for the selection of FS to be taught, i.e. "acceptable and frequent in a neutral register" (Nesselhauf, 2003:238); (2) Content: the topic of legalizing marijuana lent itself well to a class-room discussion; (3) Length: the 
video-recording took less than three minutes to watch and was therefore sufficiently short to keep the students interested.

On the basis of the transcript of the video-recording, 22 items (see Appendix A) were selected as targets according to the following criteria: 1) the sequence contains at least two words; 2) the sequence is either listed in one of the two existing German collocation dictionaries: Feste Wortverbindungen des Deutschen: Kollokationenwörterbuch für den Alltag (Häcki Buhofer, Dräger, Meier, \& Roth, 2014) and Wörterbuch der Kollokationen im Deutschen (Quasthoff, 2011), or in the German newspaper corpus of the Leipzig Corpora Collection (LCC), which can be accessed online at http:// corpora.uni-leipzig.de/.

\subsubsection{Test instruments}

To test students' productive knowledge of the targeted FS, a gap-fill exercise was designed to be used as a pre-test and a delayed post-test. Twenty-two target FS were left out from the full-length transcription text and students were asked to fill in the blanks. For all items, students' L1 (Dutch) translation was given as a prompt. In some cases, the first letter of a (part of the) target item was given to exclude other possible response alternatives.

As an immediate post-test, a sight translation task from Dutch into German was chosen. In this kind of task, students read the text in the L1 and translate it out loud in the L2. The sight translation task solicited the 22 target items and was selected because of the participants' familiarity with this task and its unequivocal productive nature. The gap-fill exercise (pre-test and delayed post-tests) can be found in Appendix $\mathrm{B}$, the immediate post-test in Appendix C.

\subsubsection{Procedure}

For each condition (attention-direction and retrieval), two types of activities were designed. The attention-directing activities consisted of 1) reading the authentic transcription text with typographic salient target FS and 2) engaging in a flash-card exercise in which the FS were translated into L1 Dutch. The retrieval activities consisted of 1) completing the FS that were left out of the transcript (gap-fill exercise) and 2) engaging in a flash-card exercise in which the FS were translated into L2 German.

The pre-test, the pedagogical intervention and the immediate post-test were performed in the fifth week of the 12 -week course. In this week, both parallel groups attended an identical two-hour class, given by the same lecturer. After a short 
introduction about the topic and objective of the class, all students completed the pre-test. They got five to ten minutes to fill in the 22 missing targets. The pre-test was announced as an introductory vocabulary exercise to see which FS were already familiar and which lexical items students would learn that day.

After all pre-tests were collected, students viewed the video-recording. Because it is known that repetition in vocabulary-focused activities is beneficial for word learning (Nation, 2013) and that the same applies for FS (Alali \& Schmitt, 2012), students were exposed to the 22 target items four times: twice when watching the video-recording and twice in the exercises that followed.

To verify students' comprehension of the video-recording, content questions were asked and answered after the first viewing. Students were encouraged to concentrate on the vocabulary and the FS used when watching the video-recording a second time. All students were already familiar with the concept of FS and the advantages of mastering FS when learning a foreign language.

Immediately after watching the video-recording, both groups received a first exercise targeting the 22 FS. In the attention-directing condition group, the transcript of the video-recording was projected on a screen and participants read the text. The 22 FS were in bold typeface and the teacher directed the attention of the learners to these FS, asking students to translate them into Dutch. In the retrieval condition group, the transcript was projected as a gap-fill exercise, in which the $22 \mathrm{FS}$ were left out. Participants had to read the text and fill in the blanks orally. Both groups received corrective feedback if a wrong (or no) answer was provided.

During the remainder of the class, students were invited to exercise their speaking skills through the discussion of other short texts. Approximately 20 minutes before the end of class, there was a second exercise to learn the 22 FS. Both groups engaged in a flashcard exercise: for all 22 targets, digital flashcards were created, using Quizlet. On one side of the flashcard, the FS was in Dutch, on the other side in German. Students in the attention-directing condition saw the phrases in German and translated them orally into Dutch; students in the retrieval condition translated the 22 FS from L1 Dutch into L2 German.

At the end of class, students of both groups completed the same immediate posttest, a sight translation from Dutch into German, containing the 22 FS. They made recordings of their oral translations and these were uploaded on the learning platform of the course. The students were accustomed to this procedure. 
In the first delayed post-test, one week later (week six of the course), and in the second delayed post-test, two months later (week 12), students of both groups were asked to fill in the blanks of the same gap-fill-exercise they had completed as a pre-test. It took them five to ten minutes.

\subsubsection{Scoring and analysis}

The pre-test and the two delayed post-tests were scored dichotomously. Partial knowledge (e.g. one correct word of a two-word phrase) was not taken into account, but accurate spelling was a prerequisite.

For the sight translation, the audio recordings of the students were analysed with a focus on the translation of the target phrases. Again, dichotomous scoring was applied: one point for a correct rendering of the phrase in German and zero for an unacceptable phrase. Pronunciation had to be satisfactory to obtain credits. In German, a mistake in the use of an umlaut (i.e. vowel alternation) for example, can change the meaning of a word, e.g. fordern (to demand) versus fördern (to support). For all tests, the maximum score was 22 , as there was a total number of 22 target items.

A mixed model repeated measures Analysis of Variance (ANOVA) was conducted. The between-group variable was the type of instruction (attention-direction and retrieval) and the within-group variable was the test score at four different points in time: 1) the pre-test, prior to the pedagogical intervention, 2) the immediate post-test, immediately after the pedagogical intervention, 3) the first delayed post-test, one week after the pedagogical intervention, and 4) the second delayed post-test, two months after the pedagogical intervention. SPSS Statistics 25 was used for the statistical analysis.

\section{Results}

\subsection{Descriptive statistics}

Both groups' mean scores and standard deviations on the pre-test and the three post-tests are listed in Table 1. Participants in the attention-directing condition scored slightly higher on the pre-test. There is a treatment effect in both groups: there are noticeable learning gains in the attention-directing condition as well as in the retrieval condition. However, learning gains in the retrieval condition seem to be higher than the learning gains in the attention-directing condition. The descriptive results also show that the attrition over time is slightly smaller in the retrieval practice condition: 
on average 2 target phrases were no longer remembered by participants in the retrieval condition, versus 2.39 in the attention-directing condition. What stands out is that students in the retrieval condition remember on average 14 out of 22 items after two months, which corresponds to the score the participants of the attention-directing condition obtained in the immediate post-test.

Table 1. Means (and standard deviations) of the scores on the target phrases for both groups. Maximum score $=22$.

\begin{tabular}{lllll}
\hline \multicolumn{5}{c}{ Time } \\
& pre-test & $\begin{array}{l}\text { immediate } \\
\text { post-test }\end{array}$ & $\begin{array}{l}\text { delayed } \\
\text { post-test 1 }\end{array}$ & $\begin{array}{l}\text { delayed } \\
\text { post-test 2 }\end{array}$ \\
\hline $\begin{array}{l}\text { Attention- } \\
\text { direction }(n=18)\end{array}$ & $5.89(1.90)$ & $14.22(2.67)$ & $13.11(3.27)$ & $11.83(3.01)$ \\
\hline $\begin{array}{l}\text { Retrieval } \\
\text { practice }(n=11)\end{array}$ & $5.27(1.73)$ & $16.45(2.11)$ & $15.82(2.82)$ & $14.45(2.70)$ \\
\hline
\end{tabular}

Data were pre-analysed to check the assumptions of normality, homogeneity of variances and sphericity, before applying a mixed ANOVA. The Shapiro-Wilk test showed a normal distribution of the data. The error variance of the dependent variable is equal across groups, based upon results of Levene's test (pre-test, $F(1,27)=.328, p=$ .572 ; post-test $1, F(1,27)=.943, p=.340$; post-test $2, F(1,27)=1.321, p=.261)$; posttest $3, F(1,27)=.016, p=.901)$. This means that the assumption of homogeneity of variances for the groups was met. The assumption of sphericity, based upon Mauchly's Test of Sphericity, was not violated, $p=.314$.

\subsection{Effect of attention-directing activities and retrieval practice}

In the mixed ANOVA, the between-subjects factor is condition (attentiondirection versus retrieval) and the within-subjects factor is time (with four different time points).

Concerning the between-subjects factor, the data analysis revealed that there was a significant main effect of condition on the learning of target items, $F(1,27)=6.09$, $p$ $=0.02, \eta_{p}^{2}=.18$. This means that participants' uptake of FS differed according to the condition. Participants of the retrieval condition scored higher on the three post-tests than their peers in the attention-directing condition group. 
Concerning the within-subjects analysis, the results demonstrated a statistically significant main effect of time, $F(3,81)=115.41, p<0.001, \eta_{p}^{2}=.81$. Contrasts revealed that participants' average score on the immediate post-test was significantly higher than on the pre-test, $F(1,27)=144.63, p<.001, \eta_{p}^{2}=.84$ and that their score on the first delayed post-test was again significantly higher than on the pre-test, $F(1,27)=123.80$, p $<.001, \eta_{p}^{2}=.82$. The score on the second delayed post-test was also significantly higher than on the pre-test, $F(1,27)=49.58, p<.001, \eta_{p}^{2}=.65$.

The analysis points to a statistically significant interaction effect between time and condition, $F(3,81)=3.63, p=0.016, \eta_{p}^{2}=.12$. This result suggests that the effect of time on the phrasal uptake is different for students engaged in retrieval activities than for students who engaged in attention-directing activities. To break down this interaction, contrasts were performed comparing differences in productive knowledge of the targets across the groups. These revealed a significant interaction when comparing the scores for the pre-test to the scores of the immediate post-test, $F(1,27)=$ $7.88, p=.009, \eta_{p}^{2}=.23$, as is illustrated by the interaction graph (Figure 1). The results of the further contrasts, which compared the immediate post-test and delayed posttests did not reveal significant interaction effects, $F(1,27)=2.17, p=.152, \eta_{p}^{2}=.07$ and $F(1,27)=0.40, p=.536, \eta_{p}^{2}=.01$. The statistical significance of the first contrast appears to result from the difference between the attention-directing and the retrieval condition, in which the slope of the line between the pre-test and immediate post-test for the retrieval condition group is steeper than for the attention-directing condition group, showing that the learning gains of participants in the retrieval condition are considerably higher immediately after the pedagogical intervention. If we look at the lines of the immediate post-test and the first delayed post-test, we see that this line is flatter in the retrieval condition group, showing that attrition after one week in this group was smaller than in the attention-directing condition group. The attrition after one week is smaller $(0.63)$ in the retrieval condition compared to the attentiondirecting condition (1.11). Looking at the line between the first and second delayed post-test, there is a similar level of decline in scores between the two groups. During this period between first and second delayed post-test, the attrition in both groups is similar: 1.28 in the attention-directing condition versus 1.37 in the retrieval condition. However, at the final test, two months after the intervention, the mean performance of the retrieval condition (14.45) is at the same level as the mean score of the attentiondirecting condition (14.22) immediately after the pedagogical intervention. 
Figure 1. Test scores of both groups over time

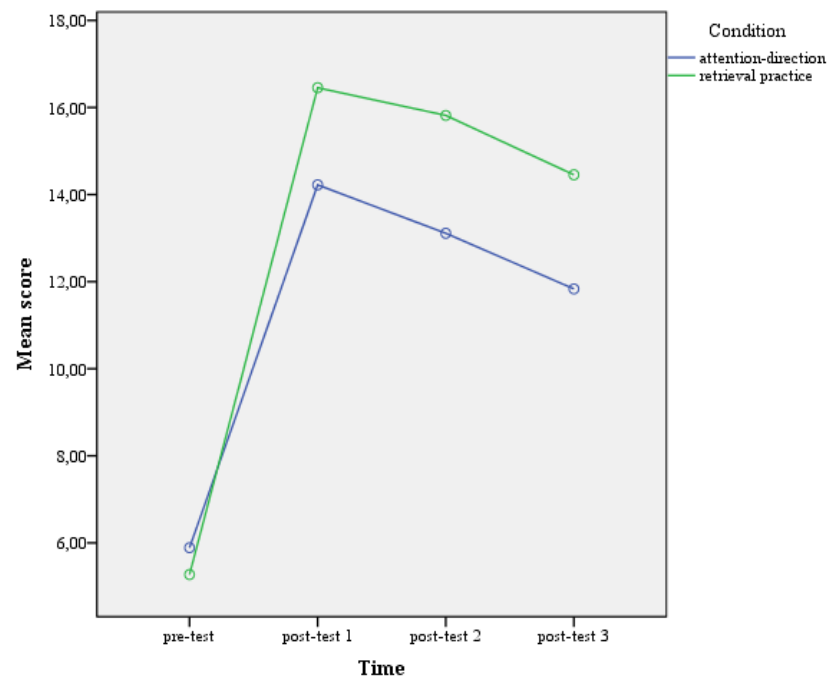

\section{Discussion}

In the current study, the merits of attention-directing activities and retrieval practice for the productive recall of German FS were compared. The main aim of this study was to see if there is a significant difference in the uptake of FS when learning FS through attention-directing activities or retrieval practice (RQ1), and if this difference in uptake is maintained over time (RQ2). Although the results demonstrate considerable learning gains in both conditions, retrieval practice led to a larger uptake of FS than attention-direction, thereby answering the first research question. Regarding the second research question, the data show that the difference in uptake is maintained over time, with better recall rates for the retrieval practice condition after two months.

With regard to the attention-directing activities, students who engaged in this condition were able to increase their productive knowledge of the 22 targets from 5.89 on the pre-test to 14.22 on the immediate post-test, 13.11 on the delayed post-test and 11.83 on the final post-test. The largest gain $(51.7 \%)$ is situated between the pre-test and the immediate post-test, which is to be expected. When we look at the attrition of this new knowledge in both delayed tests, the scores the students obtained still show a gain of $44.8 \%$ and $36.9 \%$ respectively with reference to the pre-test. These results support previous findings on awareness-raising activities when teaching FS: in order to acquire FS, foreign language learners need to notice them. Because students have difficulties noticing or identifying FS in the foreign language, pedagogical support is needed (e.g. 
Boers \& Lindstromberg, 2012). In this study, the first activity in the attention-directing condition was making the targets more salient through bold typeface. Although students were not aware of the fact that they would be tested afterwards, they still seemed to remember the targets. This is in line with the study of Peters (2012), in which typographic salience was shown to be effective for the recall of FS. As a second activity in the attention-directing condition, participants had to translate the targets from L2 into L1. This activity served to reinforce students' awareness of the form and meaning of the FS. A combination of both attention-directing activities resulted in a recall rate of the targets of 11.83 (out of 22) after two months.

The students in the retrieval practice condition scored 5.27 on the pre-test, 16.45 on the immediate post-test, 15.82 on the delayed post-test and 14.45 on the final post-test. Here too, the largest knowledge gain (66.8\%) is attested immediately after the intervention in class, after which attrition sets in. After one week, students still show a gain of $63 \%$ with reference to the pre-test and after two months of $54.9 \%$. These results provide further support for the findings of Peters and Pauwels (2015). In their study, the cued output or retrieval activities (gap filling and rephrasing activities) had a positive effect on students' awareness, cued output and spontaneous use of academic FS. Additionally, our results corroborate the findings of available studies on retrieval practice in L2 vocabulary learning (e.g. Barcroft, 2007; Goossens et al., 2014; Karpicke, 2017; Karpicke \& Roediger, 2008; van den Broek et al., 2018). More importantly, they provide much-needed evidence of the benefits of retrieval practice for L2 phrase learning.

The superior scores obtained through retrieval practice can be explained by the effort that is required from the students in retrieving and producing the target FS. According to theoretical accounts of retrieval practice, effortful retrieval is needed to acquire durable knowledge (Karpicke, 2017). Completing deleted targets in a text (retrieval condition) is more challenging for students than reading them (attentiondirecting condition). However, also the attention-directing activity with the highlighted FS, in combination with the focus on the meaning (through the translation into L1) seems to have had a positive effect. This is in line with Schmidt's (1990) noticing hypothesis, which implies that awareness of the form of input at the level of "noticing" is indispensable for foreign language learning. This, in combination with a contrastive engagement with the targets, in which students are made aware of interlingual differences as proposed in the study of Laufer and Girsai (2008), seems to be effective.

The attrition rates were similar across groups. However, the most considerable recall gain was attested in the retrieval practice group. This is consistent with the hypothesis of "pushed output" (Swain, 1985), which claims that learners improve their language development when they produce language and are "pushed" to do so. 
Participants in the retrieval practice group were pushed to produce L2-output through both retrieval activities (gap filling and translating from L1 into L2). This seems to have led to successful recall of FS in all post-tests and especially in the immediate post-test.

The attention-directing activities have not required a similar amount of effort from the students. Although students were made aware of the form (by reading the targets in bold typeface) and the meaning of the FS (by translating them from L2 into L1), this has not led to a comparable success in recall of the target FS.

\section{Conclusion}

In L2 acquisition, mastery of formulaic sequences on a productive level is one of the challenges L2 learners have to cope with. Due to the importance of FS in foreign language acquisition, there is no doubt that FS have to be addressed in class and that teachers should include explicit focus on form when teaching FS.

The comparison of the effect of attention-directing activities and retrieval practice on the acquisition and recall of FS by L2 learners, revealed that students made learning gains in both conditions. Retrieval practice, however, benefited learning more than attention-directing activities, as was evidenced by the significant higher learning gains in the retrieval condition.

There are a number of reasons why these findings should be interpreted with caution. First, due to the nature of our sample with two intact classes and because of the limited number of students learning German as a foreign language, no control condition could be added to the design. Second, the relatively modest sample of participants and the unbalanced size of the groups constrains the external validity of this study. A third limitation concerns the number of selected phrases: 22 target items is a rather limited number, considering the amount of vocabulary that university students, majoring in foreign languages, have to study. However, the range of test scores (between 11 and 18 out of 22 in the retrieval practice group, and between 6 and 17 in the attention-directing condition group) does not point to a ceiling effect.

In future research, individual difference variables such as language aptitude or working memory could be taken into account in order to see which effect different pedagogical conditions have on different learners. Individuals differ in memory and attentional capacity, which influences the extent of noticing and thus has a direct effect on SLA (Robinson, 1995). 


\section{Pedagogical implications}

Based on our findings, we make a plea for a pedagogical practice in which attention-directing activities are taken as a starting point in order to make students aware of the syntagmatic character of the language and to help them identify specific FS in the foreign language. When the aim of the language course is foreign language production, retrieval activities should also be implemented.

With this study we have illustrated that authentic material, such as short videorecordings in the L2, can be quite easily transferred into teaching material without taking up too much preparation time. Teachers can select FS that are useful for learners and turn them into learning targets through gap-fill exercises. Retrieval practice of this sort should be considered a powerful technique in language courses, not only when it comes to the acquisition of individual words, but also when it comes to the production of FS, which is far more challenging for L2 learners.

\section{References}

Alali, F. A., \& Schmitt, N. (2012). Teaching Formulaic Sequences: The Same as or Different from Teaching Single Words? TESOL Journal, 3(2), 153-180.

Bahns, J., \& Eldaw, M. (1993). Should we teach EFL students collocations? System, 21(1), 101-114.

Barcroft, J. (2007). Effects of Opportunities for Word Retrieval During Second Language Vocabulary Learning. Language Learning, 57(1), 35-56.

Barfield, A., \& Gyllstad, H. (Eds.). (2009). Researching collocations in another language: Multiple interpretations. New York: Palgrave Macmillan.

Biskup, D. (1992). L1 Influence on Learners' Renderings of English Collocations: A Polish/German Empirical Study. In P. J. L. Arnaud \& H. Béjoint (Eds.), Vocabulary and Applied Linguistics, 85-93.

Boers, F., Demecheleer, M., He, L., Deconinck, J., Stengers, H., \& Eyckmans, J. (2017). Typographic enhancement of multiword units in second language text: Typographic enhancement of multiword units in second language text. International Journal of Applied Linguistics, 27(2), 448-469.

Boers, F., Eyckmans, J., Kappel, J., Stengers, H., \& Demecheleer, M. (2006). Formulaic sequences and perceived oral proficiency: Putting a Lexical Approach to the test. Language Teaching Research, 10(3), 245-261. 
Boers, F., \& Lindstromberg, S. (2005). Finding ways to make phrase-learning feasible: The mnemonic effect of alliteration. System, 33(2), 225-238.

Boers, F., \& Lindstromberg, S. (2012). Experimental and Intervention Studies on Formulaic Sequences in a Second Language. Annual Review of Applied Linguistics, 32, 83-110.

Boers, F., Lindstromberg, S., \& Eyckmans, J. (2012). Are Alliterative Word Combinations Comparatively Easy to Remember for Adult Learners? RELC Journal, 43(1), 127-135.

Boers, F., Lindstromberg, S., \& Eyckmans, J. (2014). Is alliteration mnemonic without awareness-raising? Language Awareness, 23(4), 291-303.

Choi, S. (2017). Processing and learning of enhanced English collocations: An eye movement study. Language Teaching Research, 21(3), 403-426.

Conklin, K., \& Schmitt, N. (2008). Formulaic Sequences: Are They Processed More Quickly than Nonformulaic Language by Native and Nonnative Speakers? Applied Linguistics, 29(1), 72-89.

Council of Europe. (2001).Common European framework of reference for languages: Learning, teaching, assessment. Cambridge, U.K: Press Syndicate of the University of Cambridge.

Cowie, A. P. (1992). Multiword Lexical Units and Communicative Language Teaching. In P. J. L. Arnaud \& H. Béjoint (Eds.), Vocabulary and Applied Linguistics. $1-12$.

Durrant, P., \& Schmitt, N. (2010). Adult learners' retention of collocations from exposure. Second Language Research, 26(2), 163-188.

Ellis, N. C. (2001). Memory for language. In P. Robinson (Ed.), Cognition and Second Language Instruction 33-68.

Ellis, N. C., \& Simpson-Vlach, R. (2009). Formulaic language in native speakers: Triangulating psycholinguistics, corpus linguistics, and education. Corpus Linguistics and Linguistic Theory, 5(1).

Ellis, N. C., Simpson-Vlach, R., \& Maynard, C. (2008). Formulaic Language in Native and Second Language Speakers: Psycholinguistics, Corpus Linguistics, and TESOL. TESOL Quarterly, 42(3), 375-396.

Erman, B., \& Warren, B. (2000). The idiom principle and the open choice principle. Text - Interdisciplinary Journal for the Study of Discourse, 20(1).

Eyckmans, J., \& Lindstromberg, S. (2017). The power of sound in L2 idiom learning. Language Teaching Research, 21(3), 341-361. 
Goossens, N. A. M. C., Camp, G., Verkoeijen, P. P. J. L., \& Tabbers, H. K. (2014). The Effect of Retrieval Practice in Primary School Vocabulary Learning: Effect of retrieval practice. Applied Cognitive Psychology, 28(1), 135-142.

Granger, S. (1998). Prefabricated patterns in advanced EFL writing: Collocations and formulae. In A.P.Cowie (Ed.), Phraseology: Theory, analysis, and applications (pp. 145-160). Oxford: Clarendon Press.

Häcki Buhofer, A., Dräger, M., Meier, S., \& Roth, T. (2014). Feste Wortverbindungen des Deutschen: Kollokationenwörterbuch für den Alltag. Tübingen: Francke.

Jones, M. A., \& Haywood, S. (2004). Facilitating the acquisition of formulaic sequences: An exploratory study in an EAP context. In N. Schmitt (Ed.), Language Learning EO Language Teaching. Vol. 9:269-300.

Jones, R. L., Tschirner, E. P., Goldhahn, A., Buchwald, I., \& Ittner, A. (2006). A frequency dictionary of German: Core vocabulary for learners. London; New York: Routledge.

Kang, S. H. K., Lindsey, R. V., Mozer, M. C., \& Pashler, H. (2014). Retrieval practice over the long term: Should spacing be expanding or equal-interval? Psychonomic Bulletin Eg Review, 21(6), 1544-1550.

Karpicke, J. D. (2017). Retrieval-Based Learning: A Decade of Progress. In Learning and Memory: A Comprehensive Reference. 487-514.

Karpicke, J. D., \& Roediger, H. L. (2008). The Critical Importance of Retrieval for Learning. Science, 319(5865), 966-968.

Karpicke, J. D., \& Smith, M. A. (2012). Separate mnemonic effects of retrieval practice and elaborative encoding. Journal of Memory and Language, 67(1), 17-29.

Laufer, B., \& Girsai, N. (2008). Form-focused Instruction in Second Language Vocabulary Learning: A Case for Contrastive Analysis and Translation. Applied Linguistics, 29(4), 694-716.

Laufer, B., \& Waldman, T. (2011). Verb-Noun Collocations in Second Language Writing: A Corpus Analysis of Learners' English: Verb-Noun Collocations in L2 Writing. Language Learning, 61(2), 647-672.

Lewis, M. (1993). The lexical approach: The state of ELT and a way forward. Hove, England: Language Teaching Publications.

Lindstromberg, S., \& Eyckmans, J. (2014). How big is the positive effect of assonance on the recall of L2 collocations? ITL - International Journal of Applied Linguistics, 165(1), 19-45. 
Lindstromberg, S., Eyckmans, J., \& Connabeer, R. (2016). A modified dictogloss for helping learners remember L2 academic English formulaic sequences for use in later writing. English for Specific Purposes, 41, 12-21.

Meunier, F. (2012). Formulaic Language and Language Teaching. Annual Review of Applied Linguistics, 32, 111-129.

Meunier, F., \& Granger, S. (Eds.). (2008). Phraseology in foreign language learning and teaching. Amsterdam ; Philadelphia: John Benjamins Pub. Co.

Myles, F., \& Cordier, C. (2017). Formulaic sequence(FS) cannot be an umbrella term in SLA. Studies in Second Language Acquisition, 39(01), 3-28.

Nation, I. S. P. (2013). Learning vocabulary in another language. Cambridge ; New York: Cambridge University Press.

Nattinger, J. R., \& DeCarrico, J. S. (1992). Lexical phrases and language teaching. Oxford [England] ; New York: Oxford University Press.

Nesselhauf, N. (2003). The Use of Collocations by Advanced Learners of English and Some Implications for Teaching. Applied Linguistics, 24(2), 223-242.

Paquot, M., \& Granger, S. (2012). Formulaic Language in Learner Corpora. Annual Review of Applied Linguistics, 32, 130-149.

Pawley, A. \& Syder, F.H. (1983). Two puzzles for linguistic theory: Native-like selection and native-like fluency. In Richards J.C. \& Schmidt R.W. (Eds.). Language and communication. London, New York: Longman. 191-226.

Pérez Serrano, M. (2018). Which type of instruction fosters chunk learning? Preliminary conclusions. Revista de Lingüistica y Lenguas Aplicadas, 13(1), 133.

Peters, E. (2012). Learning German formulaic sequences: The effect of two attention-drawing techniques. The Language Learning Journal, 40(1), 65-79.

Peters, E. (2016). The learning burden of collocations: The role of interlexical and intralexical factors. Language Teaching Research, 20(1), 113-138.

Peters, E., \& Pauwels, P. (2015). Learning academic formulaic sequences. Journal of English for Academic Purposes, 20, 28-39.

Quasthoff, U. (2011). Wörterbuch der Kollokationen im Deutschen. Berlin, New York: De Gruyter.

Robinson, P. (1995). Attention, Memory, and the "Noticing” Hypothesis. Language Learning, 45(2), 283-331.

Roediger, H. L., \& Butler, A. C. (2011). The critical role of retrieval practice in long-term retention. Trends in Cognitive Sciences, 15(1), 20-27. 
Roediger, H. L., \& Karpicke, J. D. (2006). Test-Enhanced Learning: Taking Memory Tests Improves Long-Term Retention. Psychological Science, 17(3), 249-255.

Schmidt, R. W. (1990). The Role of Consciousness in Second Language Learning. Applied Linguistics, 11(2), 129-158.

Schmitt, N. (Ed.). (2004). Formulaic sequences: Acquisition, processing, and use. Amsterdam ; Philadelphia: John Benjamins Publ.

Sinclair, J. (1995). Corpus, concordance, collocation (3. impr). Oxford: Oxford Univ. Press.

Snoder, P., \& Reynolds, B. L. (2019). How dictogloss can facilitate collocation learning in ELT. ELT Journal, 73(1), 41-50.

Sonbul, S., \& Schmitt, N. (2013). Explicit and Implicit Lexical Knowledge: Acquisition of Collocations Under Different Input Conditions: Explicit and Implicit Lexical Knowledge. Language Learning, 63(1), 121-159.

Steinel, M. P., Hulstijn, J. H., \& Steinel, W. (2007). Second Language Idiom Learning in a paired-associate paradigm: Effects of Direction of Learning, Direction of Testing, Idiom Imageability, and Idiom Transparency. Studies in Second Language Acquisition, 29(03).

Stengers, H., Boers, F., Housen, A., \& Eyckmans, J. (2010). Does "chunking” foster chunk-uptake? In S. De Knop, F. Boers, \& A. De Rycker (Eds.), Fostering Language Teaching Efficiency through Cognitive Linguistics.

Swain, M. (1985). Communicative competence: Some roles of comprehensible input and comprehensible output in its development'. In S. M. Gass \& C. G. Madden (Eds.), Input in Second Language Acquisition (pp. 235-253). New York: Newbury House.

Szczepaniak, R., \& Lew, R. (2011). The Role of Imagery in Dictionaries of Idioms. Applied Linguistics, 32(3), 323-347.

Szudarski, P. (2017). Learning and Teaching L2 Collocations: Insights from Research. TESL Canada Journal, 34(3).

Szudarski, P., \& Carter, R. (2016). The role of input flood and input enhancement in EFL learners' acquisition of collocations: L2 input types and acquisition of collocations. International Journal of Applied Linguistics, 26(2), 245-265.

van den Broek, G. S. E., Takashima, A., Segers, E., \& Verhoeven, L. (2018). Contextual Richness and Word Learning: Context Enhances Comprehension but Retrieval Enhances Retention: Effects of Contextual Richness on Word Retention. Language Learning, 68(2), 546-585. 
Webb, S., \& Kagimoto, E. (2009). The Effects of Vocabulary Learning on Collocation and Meaning. TESOL Quarterly, 43(1), 55-77.

Willis, D. (1990). The lexical syllabus: An new approach to language teaching. London: Collins ELT.

Wood, D. (2006). Uses and Functions of Formulaic Sequences in Second Language Speech: An Exploration of the Foundations of Fluency. Canadian Modern Language Review, 63(1), 13-33.

Wood, D. (Ed.). (2010). Perspectives on formulaic language: Acquisition and communication. London, New York: Continuum.

Wood, D. (2012). Formulaic language and second language speech fluency: Background, evidence and classroom applications. London; New York: Continuum.

Wray, A. (2000). Formulaic sequences in second language teaching: Principle and practice. Applied Linguistics, 21(4), 463-489.

Wray, A. (2002). Formulaic language and the lexicon. Cambridge, New York: Cambridge University Press.

Wray, A. (2008). Formulaic language: Pushing the boundaries (1. published). Oxford: Oxford Univ. Press.

Wray, A. (2009). Future directions in formulaic language research. Journal of foreign languages, 32, 2-17.

Yamashita, J., \& Jiang, N. (2010). L1 Influence on the Acquisition of L2 Collocations: Japanese ESL Users and EFL Learners Acquiring English Collocations. TESOL Quarterly, 44(4), 647-668. 
Attention-direction versus retrieval practice: which fosters the productive recall of German formulaic sequences best?

\section{Appendix A}

German target phrases used in the study with their Dutch and English translation

\begin{tabular}{|c|c|c|}
\hline staatlich kontrolliert & $\begin{array}{l}\text { door de overheid } \\
\text { gecontroleerd }\end{array}$ & state controlled \\
\hline wesentlich höher & aanzienlijk hoger & considerably higher \\
\hline (bei) jungen Menschen & $(\mathrm{bij})$ jonge mensen & (among) young people \\
\hline das Risiko erhöhen & de kans verhogen & to increase the risk \\
\hline das Gehirn schädigen & $\begin{array}{l}\text { schade berokkenen aan de } \\
\text { hersenen }\end{array}$ & to damage the brain \\
\hline $\begin{array}{l}\text { die Wahrscheinlichkeit } \\
\text { liegt bei }\end{array}$ & de kans bedraagt & the probability is around \\
\hline abhängig werden & verslaafd raken & to become dependent \\
\hline zum Vergleich & ter vergelijking & for comparison \\
\hline mehr als doppelt so hoch & meer dan dubbel zo hoog & more than twice as high \\
\hline nach dem Alter fragen & naar de leeftijd vragen & to ask someone's age \\
\hline in Kontakt kommen mit & in contact komen met & $\begin{array}{l}\text { to come into contact } \\
\text { with }\end{array}$ \\
\hline harte Drogen & Harddrugs & hard drugs \\
\hline zum großen Teil & Grotendeels & in large part \\
\hline enorme Kosten & enorme kosten & huge costs \\
\hline Kosten einsparen & kosten besparen & to decrease costs \\
\hline die Rede sein von & sprake zijn van & to speak of \\
\hline ordentlich verdienen & flink verdienen & to earn decently \\
\hline gut angelegtes Geld & goed geïnvesteerd geld & money well spent \\
\hline die Nachfrage senken & de vraag doen dalen & to reduce demand \\
\hline ein Umdenken fordern & $\begin{array}{l}\text { een mentaliteitsverandering } \\
\text { eisen }\end{array}$ & $\begin{array}{l}\text { to demand a change of } \\
\text { mindset }\end{array}$ \\
\hline Schaden und Nutzen & nadelen en voordelen & $\begin{array}{l}\text { advantages and } \\
\text { disadvantages }\end{array}$ \\
\hline $\begin{array}{l}\text { Antworten finden auf die } \\
\text { Frage }\end{array}$ & $\begin{array}{l}\text { antwoorden vinden op de } \\
\text { vraag }\end{array}$ & $\begin{array}{l}\text { to find answers to the } \\
\text { question }\end{array}$ \\
\hline
\end{tabular}




\section{Appendix B}

Gap-fill exercise (pre-test and both delayed post-tests)

\section{Soll Cannabis legalisiert werden?}

Schätzungsweise jeder vierte Deutsche hat schon mal gekifft. Und das, obwohl Cannabis illegal ist. Trotz Strafverfolgung, Razzien und Kriminalisierung: der Cannabiskonsum bleibt auf stabilem Niveau. Dass Besitz, Anbau und Handel verboten sind, ist offenbar wirkungslos. Sollte Cannabis also legalisiert werden?

Deutschland wäre nicht das erste Land. Beispiel: der US-Bundesstaat Colorado: hier ist Cannabis komplett legal. Anbau, Verkauf und Konsum: alles (door de overheid gecontroleerd) s . Der Anteil der Cannabiskonsumenten an der Bevölkerung ist hier übrigens nicht oder nicht (aanzienlijk hoger) w als in anderen Ländern, in denen Cannabis illegal ist.

Trotzdem: Cannabis ist eine Droge. Ihr Wirkstoff THC kann vor allem bei (jonge mensen) $\mathrm{j}$ $\mathrm{M}$ (de kans op ... verhogen)

Psychoseund (schade berokkenen aan de hersenen) Und, (de kans) d W durch regelmäßiges Kiffen (verslaafd (te) raken) $\mathrm{zu}$ (bedraagt) b_- $9 \%$.

(Ter vergelijking) : bei Alkohol liegt sie (meer dan dubbel zo hoog)

Würden Jugendliche leichter an Cannabis kommen, wenn es legal und kontrolliert vom Staat ausgegeben würde? Möglicherweise. Jedenfalls kann sich schon jetzt jeder, z.B. hier im Görlitzer Park in Berlin Kreuzberg Marihuana besorgen. (Naar de leeftijd vragen)

die Dealer natürlich nicht. Und die Jugendlichen (in

contact komen met) hier dem kriminellen Milieu und (harddrugs) Das Gras ist oft verunreinigt, zum Beispiel mit Haarspray.

\begin{tabular}{|c|c|c|c|}
\hline $\begin{array}{r}\text { Dieser } \\
\text { vermutlich }\end{array}$ & $\begin{array}{c}\text { Schwarzmarkt würde } \\
\text { (grotendeels) }\end{array}$ & bei der & Legalisierung \\
\hline & verschwinden. & (Enorme & \\
\hline
\end{tabular}


fällt auf Cannabisdelikte. (Sprake zijn van) ein bis zwei Milliarden Euro Einsparung je nach Berechnung

Apropos Geld: bei einer kontrollierten Abgabe könnte der Staat sogar noch (flink verdienen) O

_ durch Steuern und Lizenzen für Anbau und Verkauf von Cannabis. All das wäre (goed geïnvesteerd geld) a

sogar (de vraag doen dalen) in Drogenprävention und Suchthilfe und könnte so vielleicht

Der War on Drugs, der Krieg gegen Drogen jedenfalls, sei verloren, sagen sogar der Bund Deutscher Kriminalbeamter und der Schildower Kreis, eine Gruppe von Strafrechtsprofessoren. Sie (eisen een mentaliteitsverandering) U_______________. (Nadelen en voordelen)

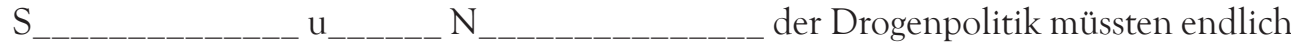
rein wissenschaftlich überprüft werden, um ehrliche (antwoorden vinden op de vraag) zu , ob und

wie eine Legalisierung von Cannabis funktionieren könnte.

\section{Appendix C}

Sight translation (immediate post-test)

Naar schatting één Duitser op vier heeft al eens geblowd. En dat hoewel cannabis illegaal is. Ondanks strafrechtelijke vervolging, razzia's en criminalisering: het cannabisgebruik blijft stabiel. Dat bezit, teelt en handel verboden zijn, heeft blijkbaar geen effect. Moet cannabis dus gelegaliseerd worden?

Duitsland zou niet het eerste land zijn. Een voorbeeld: de Amerikaanse staat Colorado. Hier is cannabis volledig legaal. Teelt, verkoop en gebruik: alles door de overheid gecontroleerd. Het percentage van cannabisconsumenten in de bevolking is hier overigens niet of niet aanzienlijk hoger dan in andere landen waar cannabis illegaal is.

Maar toch: cannabis is een drug. De werkzame stof THC kan vooral bij jonge mensen de kans op psychose verhogen en schade aan de hersenen berokkenen. En de kans, door regelmatig blowen verslaafd te raken, bedraagt ongeveer 9\%. Ter vergelijking: bij alcohol is het risico meer dan dubbel zo hoog. 
Zouden jongeren makkelijker aan cannabis geraken, als het legaal en gecontroleerd door de overheid zou worden verdeeld? Misschien wel. In elk geval kan nu al iedereen, bijvoorbeeld hier in het Görlitzer Park in Berlijn Kreuzberg, marihuana kopen. Naar de leeftijd vragen de dealers natuurlijk niet. En de jongeren komen hier met het criminele milieu en harddrugs in contact. Het weed is vaak vervuild, bijvoorbeeld met haarspray.

Deze zwarte markt zou bij de legalisering vermoedelijk voor een groot deel verdwijnen. Enorme kosten zouden zo bij politie en justitie kunnen bespaard worden, want het allergrootste deel van hun antidrugsbeleid gaat naar cannabisdelicten. $\mathrm{Er}$ is sprake van 1 tot 2 miljard euro besparing, afhankelijk van de berekening.

A propos geld: bij een gecontroleerde verdeling zou de staat zelfs nog flink kunnen verdienen door belastingen en licenties voor teelt en verkoop van cannabis. Dat zou allemaal goed geïnvesteerd geld zijn in drugspreventie en hulp aan verslaafden en zou zo misschien zelfs de vraag kunnen doen dalen.

De War on Drugs is in elk geval verloren, zeggen zelfs de Bund Deutscher Kriminalbeamter en de Schildower Kreis, een groep van strafrechtprofessoren. Zij eisen een mentaliteitsverandering. De nadelen en voordelen van het drugsbeleid moeten eindelijk zuiver wetenschappelijk gecontroleerd worden om eerlijke antwoorden te vinden op de vraag of en hoe een legalisering van cannabis zou kunnen functioneren. 